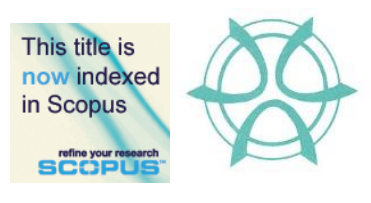

PLANNING MALAYSIA:

Journal of the Malaysian Institute of Planners

VOLUME 16 ISSUE 1 (2018), Page 15 - 24

\title{
MALAYSIA RESILIENT INITIATIVES: CASE STUDY OF MELAKA INTO RESILIENT CITY
}

\author{
Intan Syafinar Jamaludin ${ }^{1} \&$ Noralfishah Sulaiman ${ }^{2}$ \\ ${ }^{1,2}$ Faculty of Technology Management \& Business \\ UNIVERSITI TUN HUSSEIN ONN MALAYSIA
}

\begin{abstract}
Asia experienced $70 \%$ of all the disasters in the world and there is no indication that this will decline in the future. The disaster experienced by a city is mostly caused by the combination and collision of climate change, urbanization, socialeconomic instability, terrorism, natural disaster, cyber-attack, poverty, and endemic outbreak. The crisis fallen upon a city has captured attention of many audiences, thus in order to conquer the issues, city needs to be resilient in order to face and overcome the situation. Melaka was declared as a world heritage site and the government are taking serious efforts in order to maintain its heritage site by making it a resilient city. This article discusses the policy related initiatives taken by Melaka in preparing the city into resilient state. This is done by using literature and document analysis method on relevant reports, policies and literatures. The output of the research would be beneficial to the state of Melaka in the context of local authorities preparing strategic directions and managing urban development in order to become a resilient city.
\end{abstract}

Keyword: climate change, urbanization, resilience city, Malaysia, Melaka 
Intan Syafinar Jamaludin \& Noralfishah Sulaiman

Malaysia Resilient Initiatives: Case Study of Melaka into Resilient City

\section{INTRODUCTION}

As recorded in the Global Risks 2016 report (World Economic Forum, 2016), the world is facing issues of climate change, social instability, unmanageable inflation, large scale involuntary migration, biodiversity loss, terrorism, and so forth. It is forecasted that countries like Asia are likely to experience major natural catastrophes with extreme weather events (World Economic Forum, 2016). Asia accounts for $70 \%$ of natural disasters in the world (ADB, 2012). The main reason for this is because Asia Pacific lie within Pacific Ring of Fire, which accounts for $90 \%$ world's earthquakes and $70 \%$ of world's volcanoes (Jha \& Brecht, 2011).

Asia accommodate half of the world urban population and are contributing to the rising number of cities in the world. The rise of urban population will create different types of disaster threats and vulnerability (Mitchell, Enemark, \& Molen, 2015). Cities especially in the developing countries are at risk from climate threats and vulnerabilities due to high population density, unmaintained and inadequate drainage channels, concentration of solid waste, construction of large infrastructures on risky sites that disrupts natural channels and uncontrolled land development (Lavell, Wisner, Cannon, \& Pelling, 2003; and Bull-Kamanga et al., 2003). The combination of climate change together with the global environmental alterations, human societies, and urban infrastructures will further endanger human life and its surrounding environment. As such, it is critical for city to participate in becoming resilient because the risk of not becoming resilient will lead to serious decline of the economy, resources and ecosystems, and which finally will lead to loss of trust by the people.

The increasing industrialization and urbanization substantiates the research on Resilient Cities. Scholars have mentioned that the key factors influencing cities to resilient approach are the connection of urban system with environment, social, economic, infrastructure and governance. Cohen (2011) highlighted that cities that can be categorized as resilient are those working towards low carbon initiative to minimize the impact of climate change from greenhouse gases (GHG) of which cities accounted for $80 \%$ of GHG emission globally.

The Centre for Research on the Epidemiology of Disasters (2016) reports that disaster occurrence recorded in Malaysia such as floods, earthquake, storms, epidemic and transport accidents has affected more than three million people and has taken thousands of lives from year 1990 to 2016. Flash floods in Malaysian cities such as Kuala Lumpur, Melaka (Malacca) and Johor Bahru have led the Malaysian government to engage in Disaster Risk Reduction (DRR) programme and adapting climate change strategies into national agenda. Therefore, government of Malaysia has taken initiatives toward resilient approach by participating and involving in a series of sustainable action plan and disaster 
PLANNING MALAYSIA

Journal of the Malaysia Institute of Planners (2018)

mitigation plan such as Millennium Development Goals (MDGs), Sendai Framework for Disaster Risk Reduction 2015-2030, 2030 Agenda for Sustainable Development and Hyogo Framework for Actions (HFA) (EPU, 2016).

This article discusses policy related initiatives taken by Melaka Government in preparing the city into resilient state. The output of the research would be beneficial to the state of Melaka in the context of local authorities in preparing integrated strategic plans and in managing Melaka urban development in order to be resilient in the future.

\section{CONCEPT OF RESILIENCE}

The origin of the word resilience originated from middle of 17th century, it derived from Latin 'resilire', which means leap back. Subsequently the oxford dictionary defines resilience as "able to withstand or recover quickly from difficult condition". Even though resilience is a familiar word but it bears diverse interpretations across diverse contexts.

For the past few years, there has been substantial increase of publications, researches and policies that centre on resilience as the research background. The concept of resilience is one of the most important research topics in the context of achieving sustainability (Perrings, Mäler, Folke, Holling, \& Jansson, 1995; Kates et al., 2001; Foley et al., 2005). Holling (1973) was the first to introduce resilience in ecological term. Since then, resilience has been frequently redefined and extended by exploratory dimensions (Pickett, Cadenasso, \& Grove, 2004; Hughes, Bellwood, Folke, Steneck, \& Wilson, 2005).

In the context of built environment, resilience refers to one that is planned, constructed, operated, positioned and maintained in a manner that make best use of the capability of built properties and the individuals that present or work with in the built properties, to endure and recuperate from the impacts of natural hazards and man-made hazards (Bosher, Dainty, Carrillo, Glass, \& Price, 2008). In addition, the concept of resilience for urban environment or city development as defined by The Rockefeller Foundation is "the capacity of individuals, communities, institutions, businesses, and systems within a city to survive, adapt, and grow no matter what kinds of chronic stresses and acute shocks they experience" (100ResilientCities, 2016). In this article, resilience will be defined as the capacity of a city to be able to absorb, bounce back and recover from stress and shock it received.

Cities are the settlement for human, places where people gather, centre of population, cores for commerce, social, productivity, science, culture and economic development. According to United Nation (2013), cities are categorised into urban agglomeration and metropolitan area. According to World Economic Forum (2015), the top 5 global risks are the interstate conflicts, extreme weather events, failure of national government, state collapse or crisis, and high structural unemployment. The global risks have evolved with new issues 
Intan Syafinar Jamaludin \& Noralfishah Sulaiman

Malaysia Resilient Initiatives: Case Study of Melaka into Resilient City

such as terrorists attack and cyber-attacks. The survey done by World Economic Forum also showed that in the next 10 years, societal risk such as water crises and social instability along with environmental risks such as failure of climate change adaptation will be the major concern for the societies. In terms of threats that cities face, infrastructure failure, terrorism, rainfall and flood, and cyberattacks are categorised as shocks for cities, while threats such as unreliable transportation, aging infrastructure, poverty and drought falls under stresses for cities (100ResilientCities, 2016). Researches on resilient cities have helped to bridge the gap between disaster risk reduction and climate change adaptation (100ResilientCities, 2016). It moves away from traditional disaster risk management, which is founded on risk assessments that relate to specific hazards. Instead, it accepts the possibility that a wide range of disruptive events - both stresses and shocks - may occur but are not necessarily predictable.

\section{RESEARCH BACKGROUND}

\section{Profile of Melaka}

Melaka is located on the west coast of Peninsular Malaysia, bordering the states of Johor and Negeri Sembilan. It has a population of 870,000 , and is divided into 3 districts namely Melaka Tengah, Jasin and Alor Gajah with 4 local authorities (LAs). In 2008 Melaka was installed as a UNESCO World Heritage Site due to its historical value. In 2010, it was declared as a developed state by the Organisation for Economic Co-operation and Development. Being announced as world heritage site has reinforced tourism industry as one of the main economic pillars in Melaka (Goh, Tan, Lam, \& Yeo, 2012; Syakir Amir Abdul Rahman, Mariana Mohamed Osman, Syahriah Bachok, \& Mansor Ibrahim, 2014 \& 2017). Green design characteristics were adopted in parts of Melaka in order to accommodate the city heritage image and also to support urban sustainable development in order to attract tourists (Ismail \& Baum, 2006; Syakir Amir Abdul Rahman et al., 2014 \& 2017).

The disasters and challenges faced by Melaka include rainfall flooding, disease outbreak, landslide, unreliable transportation system, air pollution, declining or aging population, rising sea level and coastal flooding (100ResilientCities, 2016). The most shocking challenges in Melaka is traffic congestion particularly during weekend, public and school holidays due to people visiting historic sites around Melaka (ADB, 2014; Syakir Amir Abdul Rahman et al., 2017). Transport and industrial emission has also brought air pollution into the scenario. Melaka urban expansion and development has brought consequences associated with coastal erosion, flash flood, landslide and depleting environmental resources (ADB, 2014; Aisyah Abu Bakar, Mariana Mohamed Osman, Syahriah Bachok, \& Mansor Ibrahim , 2014). 


\section{METHODOLOGY}

This paper reviews and analyses published literature as well as government reports and policies on the issues of sustainable, green initiatives, resilience in climate change, disaster risk reduction and land use planning in order to determine the efforts and initiatives undertaken by the Malaysian Government and the Melaka State Government in pursuing resilient city.

THE EMERGENCE OF RESILIENCE CITY CONCEPT IN MALAYSIA Among the early resilient city efforts by the Malaysian Government was the implementation of the Making Cities Resilient Campaign (MCRC) in 2011 featuring Putrajaya, Melaka and Kuala Lumpur as model cities (UNISDR, 2011). MCRC was launched by the United Nations Office for Disaster Risk Reduction (UNISDR) together with local partners that included local governments and authorities with the aims to raise awareness of resilience and disaster risk reduction among the local governments and communities. The MCRC also served as a support for the execution of Hyogo Framework for Action (HFA) at the local level. Together, the MCRC and HFA support the implementation of Sendai Framework for Disaster Risk Reduction 2015-2030 at the local level (UNISDR, 2005).

\section{POLICIES EVOLUTION TOWARDS IMPLEMENTING RESILIENT CITY}

Since the Third Malaysia Plan (1976-1980), issues related to environmental distresses have been progressively emphasised and gradually formulated in the development strategies (Hezri \& Hasan, 2006). From then on, various departments and ministries have drafted policies that take into consideration the environmental interest based on unambiguous needs (Muthusamy, 2007). Following the Ninth Malaysia Plan (2006-2010), the on-going development plan and numerous national policy programmes have been co-opted to help manage the issues of climate change mitigation and adaptation (Pereira \& Tan, 2008). Meanwhile in the Tenth Malaysia Plan (2011-2015), governance has become the main focus in addressing issues of climate change and environment (EPU, 2011). In all the previous (2006-2015) Malaysia Plan, government emphasized on managing environmental distress due to climate change, and in the latest Eleventh Malaysia Plan (2016-2020) government strengthening environment for climate resilient development and resilience development against climate change and natural disasters (EPU, 2016).

Table 1: Malaysia's Initiatives towards Resilient City

\begin{tabular}{lll}
\hline No. & Initiatives Involved & Year \\
\hline 1. & Third - Eleven Malaysia Plan & $1976-2020$ \\
2. & National Physical Plan & $2005-$ current \\
3. & Land Use Planning Appraisal for Risk Areas & 2005 \\
\hline
\end{tabular}


Intan Syafinar Jamaludin \& Noralfishah Sulaiman

Malaysia Resilient Initiatives: Case Study of Melaka into Resilient City

4. National Security Council Directive no. 20

5. National Climate Change Policy (NCCP) 2009

6. KL Action Plan (KLAP) 2009

7. National Green Technology Policy (NGTP) 2009

8. Low Carbon Cities Initiatives (LCCI) 2010

Source: FTCPDPM, 2015

In line with the Malaysia Plan, as shown in Table 1, the government has initiated various policy and plan initiatives to improve the country's readiness in managing, preparing and mitigating issues of overpopulation, environmental degradation, structural failures and natural disaster in order to increase her resiliency against the unforeseen impacts. The National Climate Change Policy (NCCP) integrates national plans and policies to strengthen the resilience of development from climate change impact and to reduce adverse effect of climate change (Ministry of Natural Resources and Environment Malaysia, 2009). Meanwhile, The KL Action Plan (KLAP) 2009 was formulated to accelerate the HFA implementation through National Action Plans and to strengthen Disaster Risk Management (DRR) through empowerment of local government in DRR, adapting climate change to DRR and creating awareness among public about DRR (Asian Disaster Preparedness Centre, 2009). The National Green Technology Policy (NGTP) and Low Carbon Cities Initiatives (LCCI) were initiated by the Ministry of Energy, Green Technology and Water in 2009, parallel with the country commitment to United Nations' Framework Convention on Climate Change (COP15). The NGTP and LCCI main objective was to achieve sustainable development and subsequently reduce carbon emissions by promoting low carbon transport, and green infrastructure and technology in order to conserve environment, enhance national economy and improve quality of life.

Additionally, Land Use Planning Appraisal for Risk Areas (LUPAr) and National Physical Plan (NPP) were implemented by PLANMalaysia (formerly the Federal Department of Town and Country Planning Peninsular Malaysia). These initiatives centred on ensuring integrated land management and systematic town and country planning in Malaysia in order to achieve sustainable development, strengthen national socio-economy and introduce comprehensive safe city.

The National Security Council Directive no. 20 (The Policy and Mechanism on National Disaster and Relief Management) was also initiated by the cabinet of Malaysia through National Security Division, aiming to manage on scene incident in major disaster on land, to reduce casualties and bring the situation to normalcy (ADRC, 2016).

\section{INITIATIVES TAKEN BY MELAKA TOWARDS RESILIENT CITY}

At the state level, Melaka has been playing an active role in resilient city development. The efforts engaged by the government and LAs include policies 
PLANNING MALAYSIA

Journal of the Malaysia Institute of Planners (2018)

and projects in linking organization agencies at regional and global level in order to realise sustainability in Melaka. As shown in Table 2 below, Melaka first sustainability initiative began with the Melaka Declaration on Disaster Risk Reduction (DRR) in 2011. DRR was endorsed by Melaka State Government with main objectives to incorporate climate change adaptation and disaster risk reduction, promote community involvement, and build resilience at the local level. In 2012, the Melaka Green City Action Plan (GCAP) was established and was among the first cooperation between Indonesia, Malaysia and Thailand Growth Triangle (IMT-GT) Green City Initiatives. This involved the collaboration between the Economic Planning Unit, Malaysia (EPU) and Asian Development Bank (ADB). The purpose of the Green City Initiatives was to educate the public about climate change, global warming, green technology and green practices (ADB, 2014). Later on in 2014, Melaka engaged and consulted with International Council for Local Environmental Initiatives (ICLEI) - Local Council for Sustainability in order to promote local action for sustainable and resilient cities. In 2016, Melaka was chosen to participate in the 100 Resilient Cities Programme organized by Rockefeller Foundation, of which the programme prepares and helps cities to build resilience to the economic, social and physical challenges encountered by cities (100ResilientCities, 2016).

Table 2: Melaka's Initiatives toward Resilient City

\begin{tabular}{lll}
\hline No. & Initiatives Involved & Year \\
\hline 1. & Melaka Declaration on Disaster Risk Reduction (DRR) & 2011 \\
2. & United Nations Urban Environmental Accords (UEA) & 2012 \\
3. & Melaka Green City Action Plan (GCAP) & 2012 \\
4. & Melaka Green City State Blueprint & 2013 \\
5. & ICLEI - Local Council for Sustainability & 2014 \\
6. & Green House Emission Inventory Report & 2015 \\
7. & 100 Resilient Cities & 2016 \\
\hline
\end{tabular}

Source: Authors, 2017

City resilience focuses on improving city's performances in the face of multiple hazards, rather than preventing or mitigating the loss of assets due to specific events. Melaka state has demonstrated progressive engagement as a resilient city with the adaptation of policies and initiatives from national level to state level. This has led to the establishment of the Melaka Green Technology Council (MGTCou) to govern, monitor, plan and implement green city initiatives in the state. Concurrently Melaka Green Technology Corporation (MGTCor) was also founded to provide training pertaining to green technology, and to offer training modules based on Occupation Structure of Green Technology Industry. At the same time, LAs in Melaka have also joined the bandwagon through efforts in educating and promoting to the public programmes like household waste separation programme and no bag plastic programme. 
Intan Syafinar Jamaludin \& Noralfishah Sulaiman

Malaysia Resilient Initiatives: Case Study of Melaka into Resilient City

\section{CONCLUSION}

Despite being listed as one of the World Heritage Sites, Melaka has been facing threats in terms of resource depletion, flood, water borne diseases, coastal erosion and ecological disruptions due to expanding urban areas and increase in urban population. Therefore, the Melaka State Government has introduced city resilient initiatives by adopting series of strategies such as disaster risk reduction programme, ICLEI - Local Council for Sustainability, 100 Resilient Cities, and local plans and policies. The main interest is to bring the context of resilient city into Melaka by reducing the gap between disaster risk reduction and climate change in the mentioned policies and plans.

Even though there have been series of initiatives taken by the State Government, there is still a need for Resilient City Framework that integrates urban system in a holistic manner which includes governance, health and wellbeing, economic and social, and infrastructure and environment. It is anticipated that such a framework would assist Melaka to assess the extent of their resilience, ascertain areas of weaknesses and to classify plans to enhance Melaka city resiliency.

\section{ACKNOWLEDGEMENT}

This research is partially sponsored by Centre for Graduate Studies, Universiti Tun Hussein Onn Malaysia (UTHM).

\section{REFERENCES}

100ResilientCities (2016). Melaka's resilience challenge. Retrieved December 28, 2016 from http://www.100resilientcities.org/cities/entry/melakas-resiliencechallenge\#/-_/

Asian Development Bank [ADB] (2012). Fast facts for disaster risk management in Asian cities. Asian Development Bank, Manila.

Asian Disaster Preparedness Centre [ADPC] (2009). Regional action plan for the implementation of Kuala Lumpur declaration on DRR in Asia (KLAP). Retrieved November 1, 2016, from https://megaslides.com/doc/3287914/draft-kualalumpur-action-plan--klap

Asian Development Bank [ADB] (2014). Green city action plan: A framework for GrEEEn actions Melaka, Malaysia. Retrieved on January 7, 2017, from ttps://www.adb.org/sites/default/files/related/41571/imt-gt-green-city-actionplan-melaka-april-2014.pdf

Asian Disaster Reduction Centre [ADRC] (2016). National Security Council Directive no. 20. The policy and mechanism on national disaster and relief management. Retrieved November 1, 2016, from http://www.adrc.asia/management/MYS/Directives_National_Security_Counci l.html?Fr

Aisyah Abu Bakar, Mariana Mohamed Osman, Syahriah Bachok, \& Mansor Ibrahim (2014). Analysis on community involvement level in intangible cultural 
heritage: Malacca cultural community. Procedia - Social and Behavioral Sciences, 153, 286-297.

Cohen, B. (2011). Global ranking of top 10 resilient cities. Retrieved January 10, 2017 from http://www.triplepundit.com/2011/06/top-10-globally-resilient-cities/

Bosher, L., Dainty, A., Carrillo, P., Glass, J., \& Price, A. (2008). A proactive multi stakeholder approach to attaining resilience in the UK Building. IRec 2008.

Bull-Kamanga, L., Diagne, K., Lavell A., Lerise, F., MacGregor, H., ...\& Yitambe, A. (2003). Urban development and the accumulation of disaster risk and other lifethreatening risks in Africa. Environment and Urbanization, 15(1), 193-204.

Centre for Research on the Epidemiology of Disasters [CRED] (2016). EM-DAT, the International Disaster Database. Retrieved on October 30, 2016, from http://www.emdat.be/

Economic Planning Unit [EPU] (2006). Rancangan Malaysia Kesembilan. Retrieved 31 October, 2016, from http://www.epu.gov.my/en/rmk/ninth-malaysia-plan-20062010

Economic Planning Unit [EPU] (2016). Rancangan Malaysia Kesebelas. Retrieved 31 October, 2016, from http://rmk11.epu.gov.my/index.php/bm/kertas-strategi

Foley, J. A., DeFries, R., Asner, G. P., Barford, C., Bonan, G., ... \& Snyder, P. K. (2005). Global consequences of land use. Science, 309, 570-574.

Goh, M. L., Tan, S. H., Lam, M. S., \& Yeo, S. F. (2012). A preliminary study of perception and impact of tourism development in Malacca, Malaysia. Journal of Digital Marketing, 3(1), 39-54.

Hezri, A. A., \& Hasan, M. N. (2006). Towards sustainable development? The evolution of environmental policy in Malaysia. Natural Resources Forum, 30, 37-50.

Holling, C. S. (1973). Resilience and stability of ecological systems. Annual Review of Ecology and Systematics, 4, 1-23.

Hughes, T. P., Bellwood, D. R., Folke, C., Steneck, R. S., \& Wilson, J. (2005). New paradigms for supporting the resilience of marine ecosystems. Trends in Ecology and Evolution, 20(7), 380-386.

Ismail, H., \& Baum, T. (2006). Urban tourism in developing countries: In the case of Melaka (Malacca) City, Malaysia. International Journal of Tourism and Hospitality Research, 17(2), 211-223.

Jha, A., \& Brecht, H. (2011). An eye on East Asia and Pacific. Building Urban Resilience in East Asia, Issue 8. Washington DC: World Bank.

Kates, R. W., Clark, W. C., Corell, R., Hall, J. M., Jaeger, C. C., ... \& Svedin, U. (2001). Sustainability science. Science, 292, 641-642.

Lavell, A., Wisner, B., Cannon, T., \& Pelling, M. (2003). The vulnerability of cities: Natural disasters and social resilience. London: Earthscan.

Ministry of Natural Resources and Environment Malaysia. (2009). National policy on climate change. Retrieved April 3, 2016, from http://www.nre.gov.my/msmy/PustakaMedia/Penerbitan/Dasar\%20Perubahan \%20Iklim\%20Negara.pdf

Mitchell, D., Enemark, S., \& Molen, P. V. D. (2015). Climate resilience urban development: Why responsible land governance is important. Land Use Policy, 48:190-198

Muthusamy, S. (2007). Incorporating climate change in national economic development. In J. J. Pereira, J.J. \& M. Subramaniam (Eds.). Rapporteurs Report for the 
Intan Syafinar Jamaludin \& Noralfishah Sulaiman

Malaysia Resilient Initiatives: Case Study of Melaka into Resilient City

National Seminar on Socio Economic Impacts of Extreme Weather and Climate Change (pp. 36). June 21-22, 2006, Putrajaya, Malaysia.

Pereira, J. J., \& Tan, C. T. (2008, February). Initial findings of the Policy Study on Climate Change (NRE-RMK9). International Seminar on Climate Variability, Change and Extreme Weather Events. February 26-27, 2008, Bangi, Malaysia.

Perrings, C. A., Mäler, K.-G., Folke, C., Holling, C. S., \& Jansson, B.-O. (1995) Biodiversity conservation: Problems and policies. Dordrecht, the Netherlands: Kluwer Academic.

Pickett, S. T. A., Cadenasso, M. L., \& Grove, J. M. (2004). Resilient cities: meaning, models, and metaphor for integrating the ecological, socio-economic, and planning realms. Landscape and Urban Planning, 69, 369-384.

Syakir Amir Abdul Rahman, Mariana Mohamed Osman, Syahriah Bachok, \& Mansor Ibrahim (2014). Understanding tourists' profile and preference of tourists' destination choice: A case study in Melaka World Heritage City. Planning Malaysia, 12(3), 81-94.

Syakir Amir Abdul Rahman, Mariana Mohamed Osman, Syariah Bachok, \& Mansor Ibrahim (2017). Socio- demographic variation on tourism expenditure in Melaka UNESCO World Heritage Area. Advanced Science Letters, 23(4), 2958-2961.

United Nation Office for Disaster Risk Reduction [UNISDR] (2012). How to make cities more resilient: A handbook for local government leaders. UNISDR.

United Nation Office for Disaster Risk Reduction (2011). Press release: Malaysia commits to maintain safety of cities, schools and hospitals in lead-up to 2011 Global Platform on Disaster Risk Reduction. Retrieved October 30, 2016, from http://www.unisdr.org/files/18058_brf20110219fin.pdf

United Nations Office for Disaster Risk Reduction (2005). Retrieved October 31, 2016 , from http://www.unisdr.org/campaign/resilientcities/home/about

United Nation (2013). Towards sustainable cities. Retrieved on May 3, 2016, from http://www.un.org/en/development/desa/policy/wess/wess_current/wess2013/C hapter3.pdf

World Economic Forum (2015). Global Risks 2015. Retrieved on 4 April, 2016 from www.weforum.org/risks.

World Economic Forum (2016). Global Risks 2016. Retrieved on 26 December, 2016 from www.weforum.org 